\title{
JURISDICTION AND THE REPRESENTATION OF POWER, OR THE EMPEROR ON CIRCUIT
}

By

\section{BERNARD STOLTE}

Some inscriptions are just unlucky. Such, I believe, is the case of SEG XVII 759 , inscribed on a temple in Dmeir in Syria. It was discovered, together with two other ones - or, to be precise, one partial copy, which can be used to supplement and correct part of its twin, and another inscription - in 1934, described by Henri Seyrig, and first published by Pierre Roussel and Ferdinand De Visscher in the 23rd volume of Syria, ${ }^{1}$ with the impressum 1942-1943 but not available until 1945 and then not everywhere, though Jeanne and Louis Robert managed to report it in their Bulletin Épigraphique in the Revue des Etudes Grecques of $1944 .^{2}$ It was studied by the legal historians Arangio-Ruiz (1948), ${ }^{3}$ Wenger (1951) ${ }^{4}$ and Kunkel (1953). ${ }^{5}$ The latter revised its text, which then was printed in the Supplementum Epigraphicum Graecum XVII of 1960. Subsequently new readings were proposed by Naphtali Lewis in $1968^{6}$ and James H. Oliver studied the text again in $1974 .^{7}$ None of these publications was based on autopsy, not even the editio princeps, since its authors had to work from the notes of Seyrig. I am informed that the inscription is still in situ, but I have been unable to obtain a recent photograph. The plate supplied in the editio princeps has not been of much help. The most recent archaeological publication I have traced is a 'Vorbericht' by Elfriede Brümmer and dates from $1985 .{ }^{8}$ She corrects the plan of the temple and mentions the inscription, but does not discuss it. A set

\footnotetext{
${ }^{1}$ P. Roussel \& F. De Visscher, 'Les inscriptions du temple de Dmeir', Syria 23 (1942-1943), 173200.

${ }^{2}$ Revue des Études Grecques 47 (1944), 234, no. 181; see also 61 (1948), 206, no. 248.

3 V. Arangio-Ruiz, "Testi e documenti I. Una "cognitio" dell'Imperatore Caracalla in Syria', Bollettino dell' Istituto di Diritto Romano 49-50 (1948), 46-57.

${ }^{4} \mathrm{~L}$. Wenger, 'Ein Prozess vor Caracalla in Syrien. $\mathrm{Zu}$ einer neu bekannt gewordenen Inschrift',

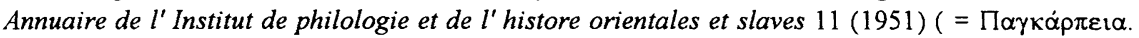
Mélanges Henri Grégoire III), 469-504.

${ }^{5}$ W. Kunkel, 'Der Prozeß der Gohariener vor Caracalla', in Festschrift Hans Lewald (Basel 1953), 81-91, repr. in W. Kunkel, Kleine Schriften zum römischen Strafverfahren und zur römischen Verfassungsgeschichte (Weimar 1974), 255-266. I quote from the latter edition.

${ }^{6}$ N. Lewis, 'Cognitio Caracallae de Goharienis: Two Textual Restorations', Transactions of the American Philological Association 99 (1968), 255-258.

7 J.H. Oliver, 'Minutes of a Trial Conducted by Caracalla at Antioch in A.D. 216', Mélanges helléniques offerts à Georges Daux (Paris 1974), 289-294.

${ }^{8}$ E. Brümmer, 'Der Römische Tempel von Dmeir. Vorbericht', Damaszener Mitteilungen 2 (1985), 55-64 with Tafel 22-25, with relevant archaeological literature.
} 
of good photographs remains a desideratum. I have based myself on the text as in SEG XVII no. 759, with the supplements proposed by Lewis. ${ }^{9}$

The importance of this inscription for our knowledge of the imperial procedure per cognitionem has been noted in Kaser's Römische Zivilprozeßrecht, and as in Hackl's second edition of this work ${ }^{10}$ it has been included in the index, there really is no longer any excuse for legal historians to ignore it. John Crook ${ }^{11}$ and Fergus Millar ${ }^{12}$ have paid it a fair amount of attention, and on this well-prepared ground I should like to discuss it because of its relevance to the 'representation of power'.

The visibility of the Roman emperor consisted not least in his jurisdiction. To quote Fergus Millar:

"The main significance of the imperial jurisdiction, however, does not lie in the execution of political enemies, or even of rich men for their wealth, but in its routine nature and often insignificant subject-matter, whose very unimportance reflects his subjects' conception of him as a source of law and justice." ${ }^{13}$

The same point had been noted at the end of the second century by Theophilus, bishop of Antioch:

"You will say to me, 'Why do you not worship the emperor?' Because he was made not to be worshipped but to be honoured with legitimate honour. $\mathrm{He}$ is not God, but a man appointed by God, not to be worshipped but to judge justly." ${ }^{14}$

The emperor as a fair judge fits well into the image of the Hellenistic king, a point we may take for granted here. The emperor has to be accessible to his subjects, who may approach him for the purpose of arbitration and adjudication and for whom he is the ultimate authority. Jurisdiction, in other

\footnotetext{
${ }^{9} \mathrm{Cf}$. also the discussion of some passages by Oliver, op.cit. (n. 7).

${ }^{10}$ M. Kaser \& K. Hackl, Das römische Zivilprozeßrecht (Munich $\left.{ }^{2} 1996\right)$.

${ }^{11}$ J. Crook, Legal Advocacy in the Roman World (London 1995), 91-95.

${ }^{12}$ F. Millar, The Emperor in the Roman World (31 BC-AD 337) (London 1977, $2^{\text {nd }}$ ed. 1992), 38, 121, 233, 455, 535-536; Idem, The Roman Near East (31 BC-AD 337) (Cambridge/ London 1993), $143,317-318$.

${ }^{13}$ Millar, op.cit. (n. 12), 240.

${ }^{14}$ Theophilus, Ad Autolycum 1.11, transl. By R.M. Grant and quoted by Millar, op.cit. (n. 12), 507 with n. 1 .
} 
words, is to them a representation of his power. On a practical level, this gives rise to the problem of availibility of the emperor, preferably in person, and if not, represented by someone who would act 'in the name of the emperor'. His subjects would of course try to present their case if the emperor happened to visit in person, or would otherwise themselves go to Rome, or, if acting as a community, send an embassy.

The case we are dealing with here is unusual. The emperor is 'on circuit'. Caracalla is in Antioch in 216, and is somehow approached by the villagers of Goaria or Goharia. I pass by the geographical problems; it may be Cehere of the Tabula Peutingeriana and is present-day Kârâ, north-east of Damascus. Suffice it to say that the temple of Dmeir must have been a cultcentre for the area east and north-east of Damascus, between that city and the desert. Strictly speaking, the villagers of Goharia have left their own province personally to address the emperor, for in 194 Syria had been divided into Syria Coele in the north, with Antioch as its capital, and Syria Phoenice in the south, to which they belong. The text tells the next stage of the story: ${ }^{15}$

In the consulship of Sabinus and Anulinus, on the [sixth] day before the Kalends of June at Antioch, when Imp. Caesar M. Aurelius Felix Augustus Parthicus Maximus Britannicus Maximus Ge[rmanicus] Maximus, having been saluted by the praetorian prefects, e(minentissimi) $v$ (iri), also by the amici and the princ(ipes) officior(um), had taken his seat in the auditorium, he ordered to be admitted Aurelius Carzeus son of Sergius ${ }^{16}$ the defensor of the Goharieni acting against Avidius Hadrianus the contractor, which cognitio the emperor deigned to undertake, with the advocate Egnatius Iulianus, while Avidius Hadrianus the contractor was with the advocate Lollianus Aristaenetus. ${ }^{17}$

Of these, Aristaenetus said: "I object". ${ }^{18}$

Lollianus said: "You have ordered that the cognitio should proceed."

\footnotetext{
${ }^{15}$ The English translation has been compiled and adapted from the works of Millar and Crook (above, nn. 11 and 12). See also the summary of the text by Oliver, op.cit. (n. 7), 291-292, whose

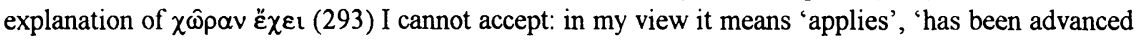
rightly', in which sense it may be found passim in Byzantine legal Greek.

${ }^{16}$ Oliver, op.cit. (n. 7), 293, prefers 'Serg(ianus)' over 'son of Sergius'.

${ }^{17}$ But see on these names below, p. 266 with n. 22.

${ }^{18}$ This is a plunge in medias res: there must have been at least a libellus with the demands of the plaintiffs.
} 
Aristaenetus said: "Cases on appeal are determined by law. Either the governor accepts the appeal and it comes to your dikasterion, or if he does not accept it, how can the case be admissible? After many hearings and verdicts you were approached with petitions from the Goharieni. A man who was neither an advocatus nor an ambassador [but ...] a private person entered a petition that you should be the judge rather than the governor. You said to him, 'If you wish me to hear it, I will hear it.' [We], having objected [from the beginning to this], now that we enter under the rules of the court [object to the case], on the grounds that they neither have a case on appeal nor can have [access to your diaksterion]." Lollianus said: "The peasants who, along with other requests, have approached you, have brought you this supplication. Cassius has not allowed the objection that they have not complained earlier. He has introduced into your imperial dikasterion with the other petitions that .... ...you have ordered that this is read ..."

(Col. II)

Antoninus Augustus said: "You say then that he has not made an appeal?"

Aristaenetus said: "They do not have a case on appeal, because it was not allowed."

Antoninus Augustus said: "Look here, let me speak according to my own opinion also in this matter. He has not made an appeal, nor has he complained, nor was this matter spoken of before the governor. 'I complain about you before the emperor', he says. Don't you wish me to hear the case?"

Aristaenetus said: "Of course."

Antoninus Augustus said: "If I were in a hurry to rise from here, I would say 'The objection is allowed'. In what, then, am I criticised?"

Lollianus said: "I will speak not more than half an hour."

And he added: "To the peasants, the case is over matters of piety, to you nothing is more important than piety. So now they have confidence in the present instance in engaging in a case before a most pious king and judge. There is a famous temple of Zeus in their territory, which is visited by people from all the neighbouring regions. They go there, and arrange processions to it. Here is the first wrong committed by our adversary. He enjoys [immunity from taxation and] exemption from liturgies, wears a 
gold crown, enjoys [precedence], has taken the sceptre in his hand and has proclaimed himself the priest of Zeus. Let him show that he has been considered worthy of that present. For I, in his presence, will read (a document) that not even his father ..."

(Col. III has been lost)

Of the many aspects that deserve our attention I single out the following. First, the most striking feature of these minutes of a hearing by Caracalla is the Latin framework, in which spoken words are reported in Greek. ArangioRuiz has suggested that the Greek is a translation from the Latin, or 'almeno che chi le [i.e., the Greek statements] ha redatte avesse maggiore familiarità col latino che col greco'. He based his suggestion on the employment of $\mu \varepsilon \dot{\mu} \phi O \mu \alpha \mathrm{l}$, frequent absence of the article, and some other incorrect Greek

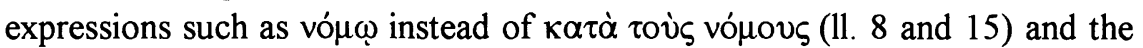
construction of the sentence at 11. 15-16. None of these cases seem to me very strong. Given the conjectural state of the text, I would refrain from inferences as to construction. I would prefer to explain supposed irregularities from the fact that all Greek here has been spoken by Romans, namely Caracalla and the two advocates. ${ }^{19}$ In addition, let us not forget that Modestinus, writing after Caracalla, makes the point that it is difficult to express Roman legal concepts in Greek (D. 27,1,1,1). A certain awkwardness should therefore not surprise us.

The development of a Greek legal language for Roman law would require a much longer treatment than I can give it here: I accept the minutes as a truthful account on this point, especially as their form is not unique. The papyri have preserved several similar cases. One thing, though, is interesting: these cases all stem from Egypt and date mostly to the fourth century and later. It has been held that not until the fourth century did Latin become the official language in court proceedings in the eastern part of the empire. If I am not mistaken, we have only one similar report from the same period as our inscription, a papyrus ${ }^{20}$ of $\mathrm{AD} 212-213$, which is of uncertain provenance, and of the date of which I am not yet entirely convinced. The Iuncinus mentioned there could be one of several possibilities; ${ }^{21}$ the editor identifies him with the Baebius Iuncinus of P.Giss. 40 II, 1. 14 - incidentally, in a constitution transmitted as the 'twin' of the constitutio Antoniniana -, and

\footnotetext{
${ }^{19}$ As already noted by Kunkel, op.cit. (n. 5), 257 n. 9.

${ }^{20}$ P.Ross.- Georg. 5.18.

${ }^{21}$ ILS 1434 (cf. RE II 2730 s.v. Baebius 29: iuridicus Aegypti) and P.Tebt. II, 46, 286 (cf. RE VI, 2603 s.v. Flavius 108).
} 
on that identification, together with a palaeographical argument, depends the dating. That papyrus apart, the inscription from Dmeir would be our oldest witness for minutes of a hearing in this form. The use of Latin in official proceedings in the East is, of course, in itself a representation of power.

Second, the persons speaking. Caracalla is there with full titulature. The two advocates have been identified by Kunkel with tolerable certainty as L. Egnatius Victor Lollianus and C. Sallius Aristaenetus, both of the senatorial order and amici of the emperor. They act for the parties in the case, Lollianus for Carzeus as defensor of the Goharieni, and Aristaenetus for the manceps, or 'contractor', Avidius. The names Iulianus and Lollianus in 11. 5-6 must be the result of confusion on the part of the mason. ${ }^{22}$ Crook lists our case as one in which the advocates are recruited from the consilium of the emperor. The suggestion of Williams that this was only to have some fun must be rejected as fanciful. ${ }^{23}$ The picture arising from this inscription shows us members of a small local community travelling at least some $350 \mathrm{kms}$ to Antioch, synchronizing their arrival with the presence of the emperor, securing a hearing and legal assistance on the highest level, getting formal procedural objections set aside and eventually — we may assume - winning their case.

Third, this is an inscription, not an archival document. To execute the inscription, however, such a document must have existed and have been available. If we had known this text from an Egyptian papyrus, we would simply have added it to our documentation of actual court cases. We would probably not have been greatly surprised about the Greek text in a Latin framework. In that sense the inscription from Syria confirms for this province what we know, or take for granted, in the case of Egypt, at a fairly early date. The presence of the emperor and his hearing of a case in deviation from normal procedure would be equally notable in both provinces, indeed anywhere in the empire.

The availability of this text in Syria need not surprise us. A copy of the acts of a case would have been handed to the parties on request. Apparently the Goharieni had asked for those minutes. But we are dealing with an inscription and therefore must assume a purpose of publicity.

To my knowledge this is one of only two inscriptions with the minutes of a case. (The other one, more fragmentary and less informative on legal procedure, is also inscribed on this temple and concerns the disappearance of

\footnotetext{
${ }^{22}$ For discussion see Kunkel, op.cit. (n. 5), 258-259.

${ }^{23}$ Cf. Crook, op.cit. (n. 11), 94.
} 
its statues; it was published together with our inscription. ${ }^{24}$ ) One may wonder what purpose they would serve. To be sure, the publication of a favourable verdict in a case may help maintaining in the future the rights of the winning party. But the full minutes? A well-known case of 'advertising' the legal position of the victorious party is the inscription of the so-called lis fullonum. ${ }^{25}$ Although many details are obscure, this much seems clear: in Rome, in $\mathrm{AD} 226$, in a cognitio procedure before the praefectus vigilum, the fullers successfully refuted a claim that they had to pay. Two further attempts to make them do so were also dealt with by praefecti vigilum, one of whom was the jurist Herennius Modestinus, already mentioned before, and were equally unsuccessful. The successive verdicts were engraved in marble. We do not know where these marble tablets were put up. They were discovered in the Esquiline region about 1700 and published by Fabretti in 1702; at some point one half got lost and the other half now is in the Capitoline Museum. Obviously publication of these verdicts aimed at advertising the rights of the fullers and deterring further attacks on them.

The publication of the full proceedings in the case of the Goharieni remains to be explained. That they must in fact have been considered to be of great significance may be inferred from the fact that they were posted up twice: first on the podium, then a second time on one of the antae. In the context of this volume, it is attractive to speculate about the significance of these inscriptions. Personally I think we cannot be greatly mistaken if we interpret them as a guarantee of the rights of the Goharieni in the appointment of a priest to the temple of Zeus Hypsistos. They were a prominent display of the imperial protection these rights enjoyed and a permanent representation of the emperor's power to protect. The choice to publish the full proceedings instead of the mere verdict, I would suggest, is connected with the special role of the emperor in this case, brought out so much more clearly in the full proceedings than in the verdict.

For it is not so much the emperor's position as a judge that is significant here, although it is of course important, but his assistance to the villagers against formal procedure and the machinery of the law. The standard procedure would have been a hearing in first instance in a local court, after which an appeal could be made to the judge $a$ quo, who, within 30 days, had to hand over to the appellant his written opinion and the acta to submit them

\footnotetext{
${ }^{24}$ See above, n. 1 .

${ }^{25}$ CIL VI, 266 = FIRA III, no. 165. Cf. F.M. De Robertis, 'Lis fullonum (CIL VI 266): Oggetto della lite e causa petendi', in W. Haase \& H. Temporini, eds., Aufstieg und Niedergang der römischen Welt II 14 (Berlin-New York 1982), 791-815.
} 
to the judge ad quem. The latter here would have been the governor, Cassius, who probably is D. Pius Cassius, governor of Syria Phoenice in $213 .{ }^{26}$ From a negative decision of the governor an appeal was open to the emperor.

The inscription permits us to see enough of the facts of this case to conclude that the formally correct procedure apparently had not been followed. There is no full agreement in the secondary literature as to where precisely the Goharieni had deviated from the royal road. Here we only note that they were pointed in the right direction by the emperor, the full measure of whose assistance therefore could only be appreciated by recording more than just the favourable verdict.

This, I submit, is the significance of the elaborate record of the case of the Goharieni. Not only was the emperor in a position and willing to consider and decide their case, but he was prepared to do so against the rules of the game, to be seen to make justice prevail over law. One wonders who had the greater interest in displaying the imperial intervention: the villagers, to whose advantage the verdict had been, or the emperor, whose power was thus represented for all to see. On balance, I think, the villagers, and one cannot exclude the pride of one of the protagonists as the moving factor. Nevertheless, the emperor would have been pleased.

Groningen, November 2002.

${ }^{26} \mathrm{PIR} \Pi^{2} 112$ nr. 479, but cf. the cautious notes of Kunkel, op.cit. (n. 5), 264-266. 